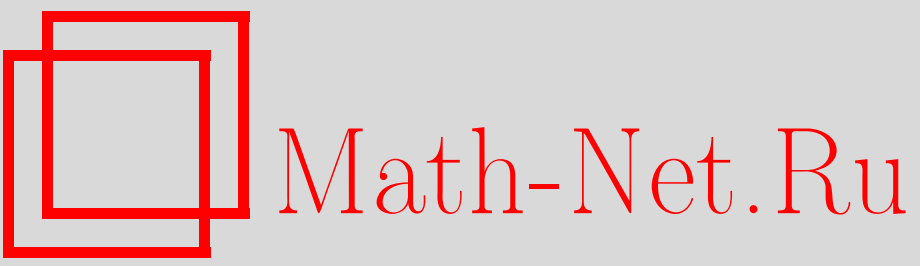

А. А. Андреев, М. Т. Дженалиев, А. Н. Зарубин, А. И. Кожанов, Е. И. Моисеев, А. М. Нахушев, В. А. Нахушева, Е. Н. Огородников, А. В. Псху, Л. С. Пулькина, Н. Р. Раджабов, В. П. Радченко, Е. В. Радкевич, О. А. Репин, К. Б. Сабитов, А. П. Солдатов, Памяти Анатолия Александровича Килбаса, Вестн. Сам. гос. техн. ун-та. Сер. Физ.-мат. науки, 2010, выпуск 5(), 6-9

DOI: https://doi.org/10.14498/vsgtu830

Использование Общероссийского математического портала Math-Net.Ru подразумевает, что вы прочитали и согласны с пользовательским соглашением http://www.mathnet.ru/rus/agreement

Параметры загрузки:

IP : 107.22 .136 .117

26 апреля 2023 г., 16:49:03 


\section{Памяти Анатолия Александровича Килбаса}

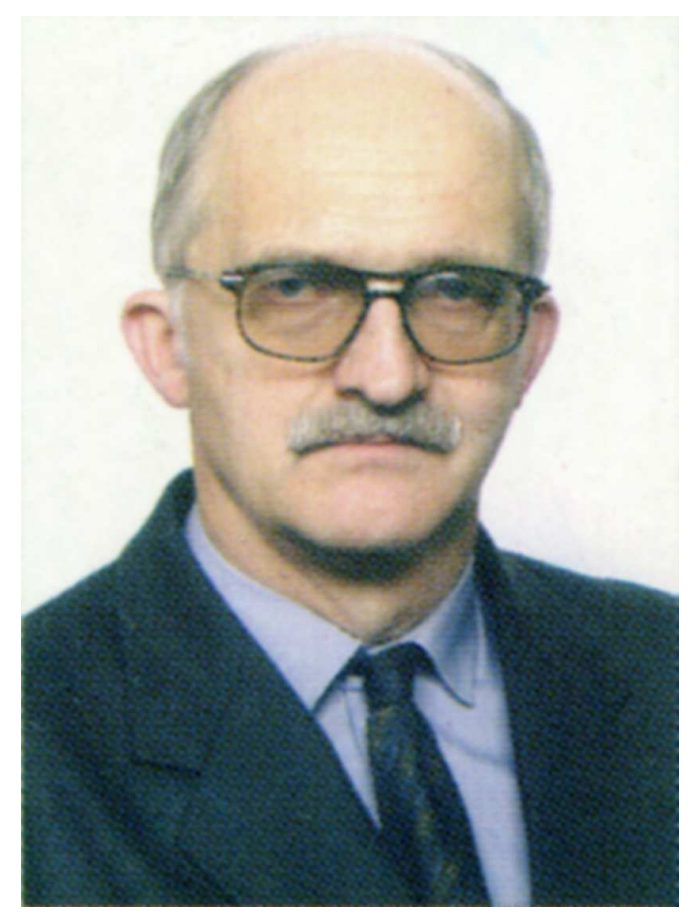

$(20.07 .1948-28.06 .2010)$

28 июня 2010 г. на 62-м году жизни нас покинул замечательный человек и учёный, известный специалист в области функционального анализа, теории функций и дифференциальных уравнений, доктор физико-математических наук, профессор Анатолий Александрович Килбас.

После получения среднего образования в школе № 6 Ново-Борисова Минской области, Анатолий Килбас в 1966 г. поступил на математический факультет Белорусского государственного университета, который закончил с отличием.

С 1971 года он начал работать в Белорусском государственном университете в должности лаборанта и прошёл все ступени: младший научный сотрудник, аспирант, старший преподаватель, доцент, профессор, с 2002 г.заведующий кафедрой теории функций.

В 1973 году А. А. Килбас поступил в аспирантуру к академику АН БССР Ф. Д. Гахову и 20 июня 1976 г. досрочно защитил диссертацию «Операторы типа потенциала со степенно-логарифмическими ядрами и интегральные уравнения, разрешимые в замкнутой форме» на соискание учёной степени 
кандидата физико-математических наук. 25 октября 1995 г. защитил в Институте математики НАН Беларуси диссертацию «Операторы дробного интегрирования. Асимптотические и композиционные свойства и приложения» на соискание учёной степени доктора физико-математических наук. Это была первая докторская защита по математике, утверждённая в Белорусском BAKe.

А. А. Килбас разработал новые функциональные, асимптотические и композиционные методы для операторов дробного интегрирования и дифференцирования и дал приложения полученных результатов к решению в замкнутой форме новых классов одномерных и многомерных интегральных и дифференциальных уравнений дробного порядка. Часть результатов представлена в монографии «Интегралы и производные дробного порядка и некоторые их приложения, 1987» (совместно с С. Г. Самко и О. И. Маричевым), расширенный и дополненный вариант которой «Fractional Integrals and Derivatives. Theory and Applications, 1993» был опубликован на английском языке. Эти монографии вызвали широкий резонанс среди специалистов по данному направлению и по сей день считаются настольными книгами специалистов, работающих в теории дробного исчисления и его приложений.

В работах, выполненных А. А. Килбасом совместно с его учениками и иностранными математиками, построена теория одномерных дифференциальных уравнений дробного порядка («Cálculo Fraccionario у Ecuaciones diferenciales Fraccionarias, 2003» в соавторстве с испанскими математиками B. Bonilla и J. J. Trujillo), а также заложены основы теории интегральных преобразований со специальной $H$-функцией в ядре, в частности с $G$-функцией Мейера и функциями гипергеометрического и бесселева типа в ядрах. Результаты исследований, давших новый эффективный подход к исследованию интегральных операторов со специальными функциями в ядрах, представлены в монографии «H-Transforms Theory and Applications, 2004» (совместно с японским математиком M. Saigo).

Анатолия Александровича отличала широта научных взглядов, о чём свидетельствует перечень основных направлений его научных исследований: дробное интегрирование и дифференцирование, интегральные уравнения, специальные функции, интегральные преобразования, дифференциальные уравнения дробного порядка, обыкновенные дифференциальные уравнения, уравнения в частных производных, асимптотические разложения, теория чисел, теория операторов.

Он был крайне работоспособным и мобильным учёным, автором более чем 420 научных и научно-методических работ. Под его руководством успешно защищены четырнадцать кандидатских диссертаций. Анатолий Александрович являлся соруководителем Минского городского научного семинара им. ак. Ф. Д. Гахова, и по сей день работающего на кафедре теории функции БГУ. Созданная им научная школа получила мировое признание.

А. А. Килбас активно участвовал в развитии совместных исследований белорусских и иностранных учёных в области функционального анализа и теории функций. Организовал и обеспечил плодотворное сотрудничество кафедры теории функций БГУ и института математики и информатики Йенского университета (ФРГ), факультета прикладной математики Фукуокского университета (Япония) и факультета математического анализа университета 
Ла Лагуна (Испания). Неоднократно принимал участие в работе международных конференций, в том числе в качестве приглашённого докладчика и члена Оргкомитета. В частности, был соруководителем секции «Дробное исчисление и приложения» на IV конгрессе международного общества по анализу, вычислениям и приложениям (ISAAC; Торонто, Канада, 2003), организатором проведения четырёх международных математических конференций в Беларуси: «Краевые задачи, специальные функции, дробное исчисление» (Минск, 1996 г.), «Аналитические методы анализа и дифференциальных уравнений» (Минск, 1999, 2001, 2003 гг.).

А.А. Килбас являлся членом Белорусского, Американского и Индийского математических обществ, являлся учёным секретарём Совета по защите диссертаций Д 02.01.07 при БГУ и членом экспертного Совета по математике ФФИ Республики Беларусь.

Несмотря на свою крайнюю занятость, Анатолий Александрович находил время для работы в редколлегиях математических журналов разных стран, в частности, он являлся членом редколлегий белорусских журналов «Вестник Белорусского университета. Сер. 1. Физика, математика, информатика», «Труды Института математики. Минск», «Веснік Гродзенскага дзяржаўнага ўніверсітэта імя Янкі Купалы. Серыя 2. Матэматыка. Фізіка. Інфарматыка, вылічальная тэхніка і ўпраўленне. Біялогія»; российского журнала «Вестник Самарского государственного технического университета. Серия: Физико-математические науки» и четырёх международных журналов: «Integral Transforms and Special Functions», «Fractional Calculus and Applied Analysis», «Advaces in Applied Mathematical Analysis», «Mathematics in Engineering. Sciense and Aerospace (MESA)». C 1985 года реферировал статьи для реферативного журнала «Mathematical Reviews» (США) и «Zentralblatt für Mathematik» (Германия).

Многократно выступая оппонентом на защитах диссертаций на соискание учёной степени кандидатов и докторов наук, А. А. Килбас дал дорогу в большую науку многим молодым учёным из России, Белоруссии, Украины, Литвы, Молдавии, Армении, Испании, Вьетнама. Будучи уже известным учёным, Анатолий Александрович много внимания уделял и повышению своей научной эрудиции и кругозора, в частности, проходил научную стажировку в ведущих мировых научных центрах: Математическом институте им. В. А. Стеклова АН CCCP; Ratgers University (New Branswick, USA); Dalian University of Technology (Dalian, China); Fukuoka University (Fukuoka, Japan); University of La Laguna (La Laguna, Spain).

Начиная с 1973 года, когда Анатолий Александрович будучи аспирантом участвовал во Всесоюзной конференции в г. Куйбышеве (с 1992 г. - г. Самара), поддерживал тесные научные и дружеские контакты с самарской научной школой по теории дифференциальных уравнений, входил в оргкомитет Всероссийской научной конференции «Математическое моделирование и краевые задачи», являлся членом редакционного совета журнала «Вестник Самарского государственного технического университета. Серия: Физико-математические науки», неоднократно приезжал в Самару на семинары с лекциями. Он был оппонентом по шести кандидатским диссертациям самарских учёных, которые сейчас успешно работают в ведущих университетах г. Самары и уже сами готовят научные кадры для высшей школы. 
Конечно, перечисление всех граней его таланта не заменит друзьям и коллегам всегда интересного общения с ним. Трудно писать «он был» об Анатолии Александровиче Килбасе, когда много раз и совсем недавно сидел с ним за столом, разговаривал о научных проблемах, о детях, семье, друзьях, университетских делах, ....

Учёный, Администратор, Преподаватель, Учитель, Человек, . . . Не нолько власть авторитета и глубина знаний привлекала к нему людей. Работая с ним рядом, сотрудники и студенты с уважением относились к его требовательности, трудоспособности, порядочности, человечности, ценили в нём натуру умную и тонкую, человека, хорошо знающую культуру и историю не только своей Родины, но и многих стран мира.

У Анатолия Александровича было и остаётся много искренних почитателей его личности и таланта, обязанных ему своим становлением в науке и в жизни вообще.

Светлая память об Анатолии Александровиче Килбасе навсегда сохранится в сердцах всех знавших его людей.

Андреев А.А., Дженалиев М.Т., Зарубин А.Н., Кожанов А.И., Моисеев Е.И., Нахушев А.М., Нахушева В.А., Огородников Е.Н., Псху А.В., Пулъкина Л.С., Раджабов Н.Р., Радченко В.П., Радкевич E.B., Репин О.А., Сабитов К.Б., Солдатов А.П. 